\title{
Influências de Manuel Bandeira, Carlos Drummond de Andrade e João Cabral de Melo Neto na poesia de Ruy Belo
}

Manaira Aires Athaydel Universidade de Coimbra / CAPES

\begin{abstract}
"A nós, portanto, as mais diversas influências. E que nos venham depois dizer que as tivemos".
\end{abstract}

Ruy Belo².

${ }^{1}$ Desenvolve no Doutoramento em Estudos Avançados em Materialidades da Literatura, da Faculdade de Letras da Universidade de Coimbra, a tese «Ruy Belo e o modernismo brasileiro. Poesia, espólio». É a organizadora do livro de ensaios Ruy Belo, Homem de Palavra[s], com textos inéditos sobre o poeta escritos por reconhecidos críticos portugueses e brasileiros, dentre eles Eduardo Lourenço, Gastão Cruz, Ida Ferreira Alves, Jorge Fernandes da Silveira, Nuno Júdice, Vasco Graça Moura. Integra também a produção do documentário Ruy Belo, Era Uma Vez, de Nuno Costa Santos, produzido pela Zulfilmes em parceria com a RTP e a Fundação Calouste Gulbenkian. Tem publicado vários artigos sobre a poesia beliana em revistas de referência, como a Colóquio/Letras (Fundação Gulbenkian, Portugal), a Granta/Portugal e a Estudios Portugueses (Universidade de Salamanca, Espanha). Investiga o espólio do poeta desde 2010.

2 BELO, 2002, p. 286. 
E ste ensaio elabora um percurso pela obra poética beliana que reconhece influências da poesia de três dos principais poetas brasileiros do século XX, tentando perceber de que forma as produções de Manuel Bandeira, Carlos Drummond de Andrade e João Cabral de Melo Neto foram assimiladas na construção do discurso poético de Ruy Belo. Contudo, não se trata aqui de entender a influência em poesia como uma simples transmissão de ideias e de imagens, isto seria uma questão "meramente de temperamento e de circunstância"3, como diria Harold Bloom. É preciso compreender, nesse caso, de que forma dá-se esse "agon", ou combate criativo, refletindo sobre várias dinâmicas de intertextualidade, desde relações de ordem temática, ecfrástica ou de transposição poética, com a partilha de núcleos simbólicos e a partir de influências voluntárias, a mecanismos onde as influências passam a ser ressonâncias, fazendo parte, muitas vezes inconscientemente, da seiva que sustenta o tronco discursivo poético, quer dizer, que se infiltra no tecido poético ${ }^{4}$. Até mesmo porque, de uma forma ou de outra, "a influência é um local de confronto" ${ }^{\text {, }}$, onde a apropriação "implica as imensas angústias da dívida", a que Ruy Belo responde afirmando que "a maneira de saldar dívidas desta natureza é simplesmente contraí-las" ${ }^{\prime 7}$, para mais porque "a influência é também um meio de convívio [...], é um acto de

${ }^{3}$ BLOOM, 1991, p. 84.

${ }^{4}$ Ruy Belo escreve: "Para experimentar as suas forças um poeta enxerta na sua obra um segmento alheio, oriundo de qualquer domínio cultural maxime da poesia nacional ou estrangeira. E a árvore, que confinada aos seus próprios limites estaria condenada à morte ou à menoridade, ensaia novos ramos, percorridos pela mesma seiva" (BELO, 2002, p. 284).

${ }^{5}$ BELO, 2002, p. 284.

${ }^{6}$ BLOOM, 1991, p. 7.

${ }^{7}$ BELO, 2002, p. 285. 
homenagem porque só se é influenciado por um poeta que se admira"s.

Diga-se desde logo, aliás, que Manuel Bandeira ${ }^{9}$ é o poeta brasileiro com quem Ruy Belo estabelece maior ligação. Não se trata apenas de delinear referências diretas como em "In memoriam"10, onde Ruy Belo se despede do mestre então há pouco falecido, ou se ficar simplesmente nos ensaios que escreveu sobre ele ${ }^{11}$ (seria, assim, uma análise bastante superficial e óbvia), mas compreender como na gênese discursiva de Ruy Belo é troncular a poesia de Manuel Bandeira. E Homem de palavra(s), o quarto dos noves livros publicados em vida pelo poeta português, traz-nos uma alargada arena para esta investigação.

${ }^{8}$ BELO, 2002, p. 284.

${ }^{9}$ E aqui não esqueçamos do "jeito de Portugal" de Manuel Bandeira, como assim a ele se referiu Mário de Andrade numa carta datada de 1925, expressão que veio a ser ratificada por críticos como Tristão de Ataíde, Adolfo Casais Monteiro, Henrique Galvão e Arnaldo Saraiva ao afirmarem que grande parte do lirismo e da linguagem de Bandeira é de fonte lusitana, numa poética nomeadamente luso-brasileira, "muito portuguesa nas raízes, muito brasileira nos ramos", diria Henrique Galvão (GALVÃO, 1956, p. 1).

${ }^{10}$ Onde diz que "O poeta pode ser fraco pode ser forte / por vezes vai dar uma volta e demora" e continua: "A treze de outubro foram-se embora / manuel bandeira e cristovam pavia / Todas as mortes nos matam um pouco / seja a de um santo seja a de um louco / Na irmã morte viva a poesia: / Viva bandeira viva pavia" (BELO, 1997, p. 84). ${ }^{11}$ Ruy Belo realizou, para a conclusão de uma especialização em 1966, os trabalhos "Manuel Bandeira em verso e prosa" e "Manuel Bandeira ou como um poeta se faz", que três anos mais tarde publicou em Na senda da poesia (vale ressalvar que "Manuel Bandeira em verso e prosa" já havia sido publicado na separata da revista $O$ tempo e 0 modo, números 62-63, em 1968). 
Vejamos, por exemplo, os poemas "Na praia" e "O valor do vento":

\section{Na praia}

Raça de marinheiros que outra coisa vos chamar senhoras que com tanta dignidade à hora que o calor mais apertar coroadas de graça e majestade entrais pela água dentro e fazeis chichi no mar? ${ }^{12}$

\section{O valor do vento}

Está hoje um dia de vento e eu gosto do vento

O vento tem entrado nos meus versos de todas as maneiras e só entram nos meus versos as coisas de que gosto

$\mathrm{O}$ vento das árvores o vento dos cabelos $o$ vento do inverno o vento do verão

O vento é o melhor veículo que conheço Só ele traz o perfume das flores só ele traz a música que jaz à beira-mar em agosto Mas só hoje soube o verdadeiro valor do vento O vento actualmente vale oitenta escudos Partiu-se o vidro grande da janela do meu quarto ${ }^{13}$

É possível observar que em ambas as composições Ruy Belo emprega uma das técnicas mais utilizadas por Manuel Bandeira, que é a de estabelecer a divisão do verso "sempre que surge uma nuança da idéia, uma imagem ou um detalhe a destacar, obedecendo assim o poeta 'à certains conditions physiologiques de rythme' (Marcel Jousse), de acôrdo com

\footnotetext{
${ }^{12}$ BELO, 1997, p. 120.

${ }^{13}$ BELO, 1997, p. 101.
} 
'une image physique suggestive de la danse des sentiments et des idées dans notre moi sensible e intellectuel' (André Spire)"14. Recordando ser Manuel Bandeira "quem, pela primeira vez entre nós, empregou o verdadeiro verso livre"15 e, não obstante, Ruy Belo corroborar ao longo de toda a sua obra o seu incansável exercício de versificação ${ }^{16}$ (daí o ritmo ser a grande obsessão formal beliana), é nesse desdobramento de ritmo atrelado à composição da imagem poética que há o que Ruy Belo chama de "proposições", quer dizer, imagens geralmente retiradas de cenas do cotidiano e que funcionam como "unidades aglutinadoras" em sua poesia ${ }^{17}$. Essas cenas ou situações do cotidiano (por vezes marcadas pela linguagem coloquial) são revolvidas pelo humor perspicaz, pela ironia ou pelo afloramento anedótico ou paródico. Não raramente é ainda deixada ao leitor a tarefa de preencher as elipses narrativas e entender a história por trás da história contada, como quando em "O valor do vento" o tom lírico é quebrado pelos dois versos finais ("O vento actualmente vale oitenta escudos / Partiu-se o vidro grande da janela do meu quarto"), em que cabe ao leitor calcular qual é o valor do vento. Ou então em "Requiem por um bicho", com apenas os seus dois versos: "Está tudo muito certo mas a gata / que outro mundo trará a gata que morreu?"18.

Nesses traços de poemas de Homem de palavra(s) podemos reconhecer a têmpora de Manuel Bandeira, evocando o que Adolfo Casais Monteiro chamaria de "a lição da simplicidade"

\footnotetext{
${ }^{14}$ MORAES, 1962, p.188.

${ }^{15}$ HOLANDA, 1990, p. 13.

${ }^{16}$ Cf. BELO, 2009, p. 855.

${ }^{17}$ Como afirma no prefácio da segunda edição de Homem de palavra(s): "eu conquisto os meus poemas palavra a palavra mas sempre passo pela proposição como unidade aglutinadora" (BELO, 1997, p. 32). ${ }_{18}$ BELO, 1997, p. 52.
} 
ou "a vacina anti-retórica"19. Portanto, em muitos dos poemas de Ruy Belo que dialogam, voluntaria ou involuntariamente, com a poesia bandeiriana, o cotidiano ${ }^{20}$ surge em fasquias de memória embrulhadas pelo tom irônico ou chistoso ou pelo humor enternecido, que em Bandeira delineia uma forma "mais sã e gratuita" 21 em Libertinagem (livro com que definitivamente afirma a sua autêntica e completa mensagem de poeta modernista ${ }^{22}$ ), de 1930, e que em Ruy Belo está presente desde o início de sua produção poética mas ganha ar de liberto em Homem de palavra(s). Por isso, podemos dizer, salvas as proporções, que Homem de palavra(s) está para a obra de Ruy Belo como Libertinagem está para a obra de Manuel Bandeira. Em poemas de Libertinagem como "Pneumotórax", "Porquinho-da-índia", "Pensão familiar" e "Poema tirado de uma notícia de jornal", por exemplo, a poesia é depositada em pequenos núcleos, como uma observação, como uma sugestão, onde grande importância é concedida ao desfecho ou ao arrebatamento do poema, conforme reconhecemos também em Ruy Belo.

Aí está inteira a simplicidade máxima da poesia totalmente desadornada, que raramente está na beleza isolada de um verso, mas quase sempre na "construção"

${ }^{19}$ MONTEIRO, 1968, p. XVI.

${ }^{20}$ Por vezes apresentado sob a ideia da "vida besta" a que se refere Manuel Bandeira em seu Itinerário para Pasárgada, de 1966, para aludir à vida cotidiana em seus atos de repetição, que, justamente por serem bisados, pouca significância lhes é dada. A expressão (da qual, inclusive, Drummond já tinha se apropriado no poema "Cidadezinha qualquer", em Alguma poesia, de 1930) em muito chamou a atenção de Ruy Belo, sendo sublinhada todas as vezes que aparece no livro Manuel Bandeira: análise e interpretação literária, de Emanuel de Moraes.

${ }^{21}$ MONTEIRO, 1968, p. XXV.

${ }^{22}$ Cf. MONTEIRO, 1968, p. XX. 
emocional e mental que se vai erguendo em nós à medida que os versos se vão acrescentando aos versos, e o contraponto das imagens subindo à tona da memória do poeta se vai traduzindo para nós na visão dum mundo ignorado. ${ }^{23}$

Manuel Bandeira e Ruy Belo, poetas exímios da quotidianidade, não fizeram da descoberta do cotidiano um simples processo, pois como podemos ver, muitos dos poemas citados estão para além da pura anotação. Como "nunca será de mais repetir que poesia é imediatamente linguagem, é estilo e, se o for, só mediatamente é vivência" ${ }^{24}$, o sentido do cotidiano não é propriamente um esquecimento do essencial por este nem sempre estar na essencialidade dos temas. "O quotidiano pode ser, para os verdadeiros poetas, tão rico de ressonâncias eternas e intemporais como o tema mais alheio ao quotidiano"25. Quer dizer, uma poesia assente no corriqueiro, na vida diária não significa uma poesia que não saiba olhar para o intemporal, para o essencial, para o eterno, e problematizá-los.

É o que vemos, por exemplo, em "Exercício", poema de Ruy Belo que chama a atenção pela referência direta que faz a um verso de Bandeira - inclusive, o poema foi intitulado inicialmente "À MEMÓRIA DE MANUEL BANDEIRA", como podemos conferir em seu autógrafo (Figura 1). Na composição, o poeta começa por povoar o dia denunciando o vento que "anima a roupa / suspensa desta ou daquela janela" e relata o café como "a minha grande esperança"26. "Agora que o tomei / com pressa e frenesim até / o que vai ser a vida ainda não sei"27.

${ }^{23}$ MONTEIRO, 1968, p. XXVI.

${ }^{24}$ BELO, 2002, p. 286.

${ }^{25}$ MONTEIRO, 1968, p. XXVI.

${ }^{26}$ BELO, 1997, p. 88.

${ }^{27}$ BELO, 1997, p. 88. 
E prossegue: "Mosteiro dos jerónimos fachada / impassível ao vão vaivém humano / aqui ando eu perdido de ano em ano / ó vida noves fora nada" ${ }^{28}$. Neste verso final está contida a referência a "Vida noves fora zero", o conhecido verso ${ }^{29}$ do poema de Manuel Bandeira que coincidentemente se chama "Belo belo II", do livro Belo belo, de 1948, o sétimo dos onze livros que o poeta publicou em vida.

Tanto em "Belo belo II" quanto em seu antecessor "Belo belo", publicado no livro anterior Lira dos cinquent'anos, de 1940 - aliás, poema este que termina com o verso "-Quero a delícia de poder sentir as coisas mais simples", que Ruy Belo reitera em seu ensaio "Manuel Bandeira em verso e prosa" conformando Bandeira como o poeta "de naturalidade e de simplicidade" 30 e de "ternura expressamente afirmada" ${ }^{31}$, características que parecem interessar ao próprio Ruy Belo impetrar em sua poesia,

${ }_{28}^{28}$ BELO, 1997, p. 88.

${ }^{29}$ Inclusive várias músicas fazem referência ao verso, dentre elas "Noves fora", de Fagner e Belchior, que ficou conhecida na voz de Elis Regina, com versos que indicam somas, subtrações e divisões: “É tudo ou nada / Noves fora, nada / A tua falta somada / A minha vida tão diminuída / Com esta dor multiplicada / Pelo fator despedida". Há também a música "Bandeira", de Zeca Baleiro, cujo final é "Nada tenho vez em quando tudo / Tudo quero mais ou menos quanto / Vida, vida noves fora zero / Quero viver, quero ouvir, quero ver". Outra música de Zeca Baleiro, mas agora em parceria com Chico César, também revela a influência dos poemas "Belo belo" e "Belo belo II" no processo de composição. Em "Eu detesto Coca Light" temos "Tolerância zero, fome zero, coca zero / No quartel do mundo, eu sou o recruta zero / Quero, quero tanta coisa / E só me dão o que não quero". Aqui há também uma referência ao Recruta Zero, personagem criado pelo cartunista Mort Walker nos anos 50 e que ficou famoso por sua preguiça que causa situações embaraçosas e engraçadas.

${ }^{30}$ BELO, 2002, p. 234.

${ }^{31}$ BELO, 2002, p. 230. 
e aqui lembremos de versos como, por exemplo, "Éramos jovens gostávamos acima de tudo de coisas simples" ${ }^{\prime \prime 2}$, com que começa "Esse dia no miradouro da boca do inferno" - há uma poética tomada pelo ar pueril, quase como numa lengalenga de criança, mas na qual, contudo, detecta-se uma ingenuidade atenciosa, como quem, depois de descobrir o mundo, está a colocar limites entre o que quer e o que não quer. $O$ final desta saga em dois poemas é o próprio verso "Vida noves fora zero", que une a ideia da prova dos noves, também chamada de noves fora ${ }^{33}$, com a própria noção de insignificância ou mesmo de inutilidade da vida, aqui engajada pelo zero e a sua associação ao vazio (ou ao nada, com que Ruy Belo o substitui em sua versão).

32 BELO, 2009, p. 651.

${ }^{33}$ É um método que permite verificar se uma conta, seja ela de qual das quatro operações for, está correta. O que se faz é retirar os noves ao divisor e em seguida os noves ao quociente. Depois, multiplica-se os números encontrados e tira-se os noves; adiciona-se este resultado ao resto e tira-se novamente os noves. Se o último número for igual ao encontrado depois de tirados os noves ao resto, a conta está certa. 


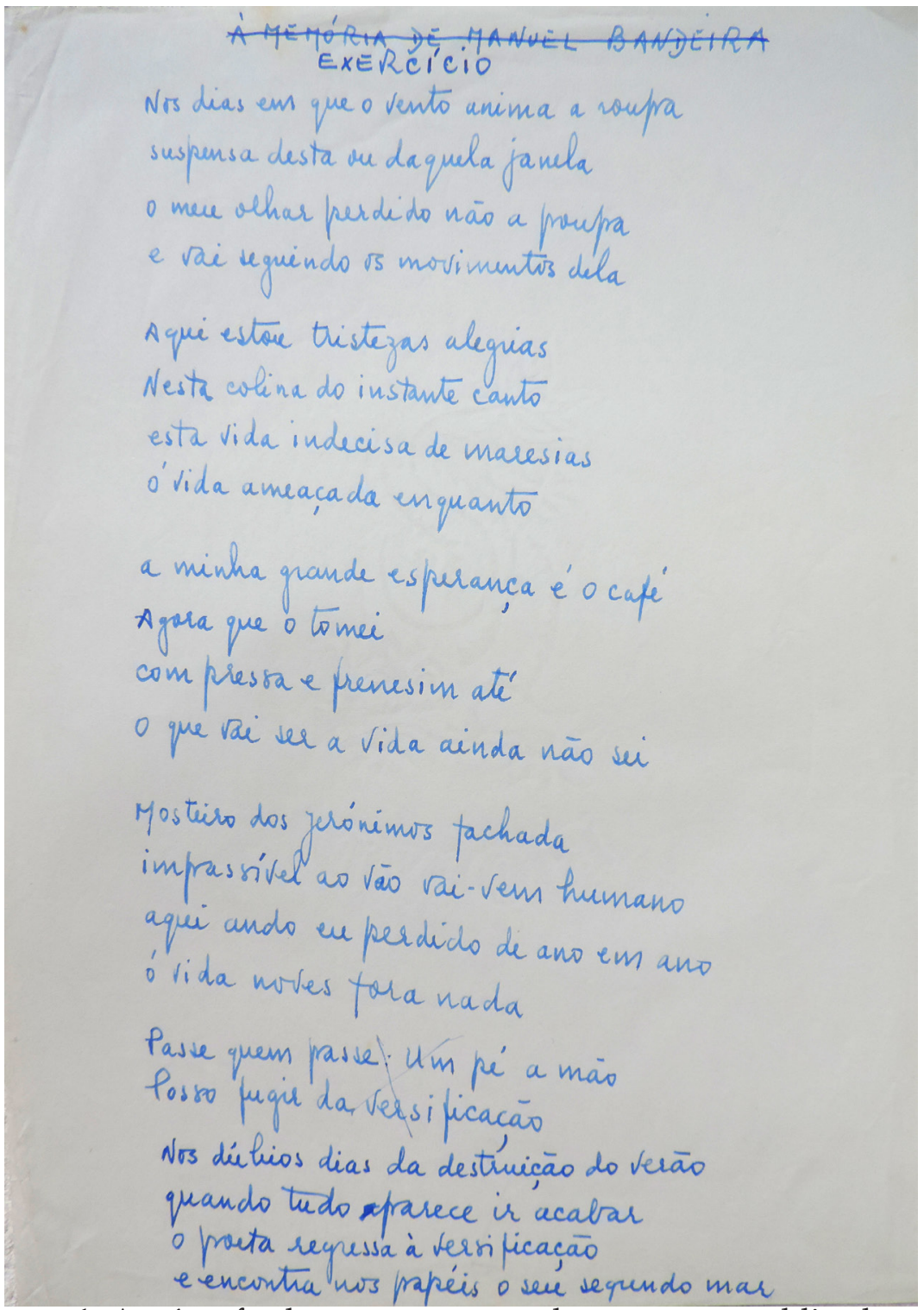

Figura 1. Autógrafo do poema que acabou por ser publicado em Homem de palaura(s) com o título "Exercício", embora, como vemos na imagem, tenha sido intitulado inicialmente de "À MEMÓRIA DE MANUEL BANDEIRA". 
Temos, assim, nestes dois Belos belos ${ }^{34}$ um temperamento lírico que em "Vou-me embora pra Pasárgada", um dos últimos poemas de Libertinagem, timidamente já se anunciava e que ganha consubstanciação, só que com uma seiva diferente, nas obras seguintes, então Estrela da manhã (1936), Lira dos cinquent'anos (1940) e o próprio Belo belo (1948). Os alumbramentos prolíferos do período de Libertinagem, com a "revolta contra a primitiva atitude [hermética, lúgubre, amargurada] do poeta" 35 , são cessados. Dilui-se a atmosfera regente em Libertinagem, em que o quarto fechado deu lugar às cortinas abertas e o cheiro de casa envelhecida foi dispersado por uma nova arrumação, onde o poeta se despertou "para tudo o que até aí olhava como frutos proibidos" ${ }^{\prime 36}$. Em suma, passou aquela alegria entusiasta e militante até de quem queria cravar o seu lugar com o lirismo de libertação numa transposição direta da própria realidade sentida - como diria Ruy Belo num outro poema de Homem de palavra(s), "Esta rua é alegre", e que em muito se associa a este tom lírico pós-Libertinagem, "Não costumo por norma dizer o que sinto / mas aproveitar o que sinto para dizer qualquer coisa" ${ }^{137}$.

Esse lirismo enternecido e desconsolado (mas não mais desolado, como nas primeiras obras de Bandeira), diferente dos poemas que aqui citamos inicialmente com outras marcas estilísticas, também está presente em Ruy Belo desde as primícias de sua produção poética, em poemas onde vamos encontrar sobretudo a obsessão da morte, a alegria fugaz ou fantasiada e o apelo às memórias de infância, três motes temáticos em comum que acompanham Ruy Belo e Manuel

${ }^{34}$ E lembremos ainda da herança desses poemas em "Quero só isso nem isso quero", de Toda a terra.

${ }^{35}$ MONTEIRO, 1968, p. XXIV.

${ }^{36}$ MONTEIRO, 1968, p. XXV.

${ }^{37}$ BELO, 1997, p. 85. 
Bandeira ao longo de todas as suas produções poéticas e que vão ganhando diferentes tratamentos a cada fase, de modo que nos ajuda a estudar as várias direções da evolução de suas poesias e a confrontar os seus percursos. "No 'Vou-me embora p'ra Pasárgada', Manuel Bandeira diz isto com outra temperatura poética", escreve Ruy Belo na marginália de um exemplar da primeira edição de Aquele grande rio Eufrates (Figura 2), a propósito de "Saudades de melquisedeque", onde lemos:

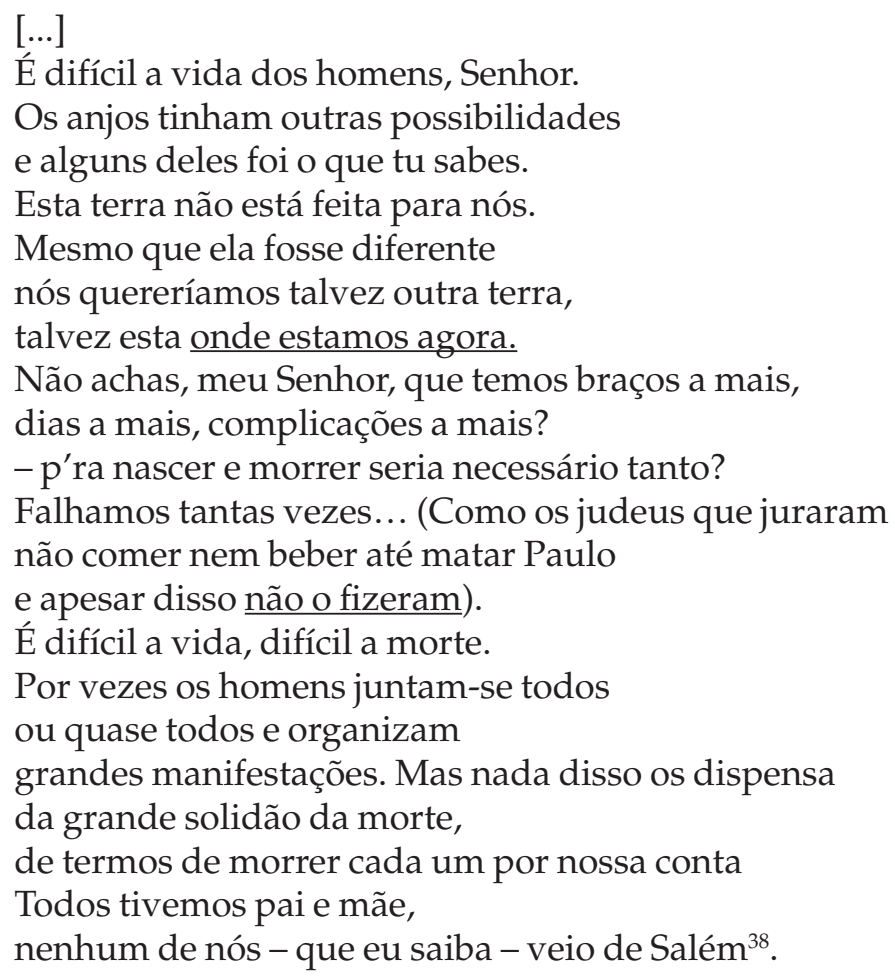

${ }^{38}$ BELO, 1961, pp. 47 e 48 (sublinhado nosso). 
Os versos sublinhados acima foram assinalados conforme Ruy Belo o fez num exemplar da primeira publicação, introduzindo as alterações que vieram a ser incorporadas na segunda ediç̧ão, em 1972. Para além de eliminar todos os sinais de pontuação (exceto as interrogações) e escrever os lexemas em minúsculo - recursos que começaram a ser adotados a partir de Homem de palavra(s), conforme já mostramos -, o verso "talvez esta onde estamos agora" se torna "talvez esta de que agora dispomos", numa mudança que em vez de dar ênfase à localização no espaço ("onde estamos") e no tempo ("agora"), como no verso da primeira versão, passa sutilmente a anuir a transitoriedade da estadia e a aceitação diante do que então é possível de se ter. O segundo verso modificado é "e apesar disso não o fizeram", reescrito como "e apesar disso não o mataram", potencializando o verbo matar com a sua repetição, já que aparece no verso anterior.

Essa terra que nunca é feita para nós (porque nunca corresponde aos nossos ideais e, assim sendo, permanece sempre como um ideal), essa terra de Ruy Belo é uma curiosa mistura entre a Pasárgada de Bandeira e a Salém de Melquisedeque (daí o título do poema). Melquisedeque, que aparece sobretudo no Livro de Gênesis, era conhecido como o Rei da Terra, o que "instruiu os povos e lhes deu a civilização" ${ }^{39}$, e na terra construída pelo poema beliano talvez essa civilização seja a "outra civilização" que é a própria Pasárgada. "Em Pasárgada tem tudo / É outra civilização" 40 , já dizia Bandeira. O interessante aqui é observar como Ruy Belo constata que tanto no poema bandeiriano ${ }^{41}$ quanto na história bíblica de

${ }^{39}$ Cf. Hebreus 7:1-3.

${ }^{40}$ BANDEIRA, 1990, p. 222.

${ }^{41}$ Em Itinerário para Pasárgada, Manuel Bandeira conta que “'Voume embora pra Pasárgada' foi o poema de mais longa gestação em toda a minha obra. Vi pela primeira vez esse nome de Pasárgada 
Melquisedeque há uma estirpe mitológica associada a uma terra, onde a liberdade é jazente. Quer dizer, a própria capacidade simbólica-imagética da mitologia em sua anuência para explicar o surgimento (de uma terra, por exemplo) é detectada enquanto denominador comum e associativo do poema e da história, mas Ruy Belo utiliza magistralmente essas referências para criar a sua própria terra, cujo temperamento peculiar é assomado no poema pela maior preocupação de sua poesia, a morte.

quando tinha os meus dezesseis anos e foi num autor grego. Estava certo de ter sido em Xenofonte, mas já vasculhei duas ou três vezes a Ciropedia e não encontrei a passagem. [...] Esse nome de Pasárgada, que significa 'campo dos persas' ou 'tesouro dos persas', suscitou na minha imaginação uma paisagem fabulosa, um país de delícias, como o 'L'invitation au voyage' de Baudelaire. Mais de vinte anos depois, quando eu morava só na minha casa da Rua do Curvelo, num momento de fundo desânimo, da mais aguda sensação de tudo o que eu não tinha feito na minha vida por motivo da doença, saltou-me de súbito do subconsciente esse grito estapafúrdio: 'Voume embora pra Pasárgada!'. Senti na redondilha a primeira célula de um poema, e tentei realizá-lo mas fracassei. Abandonei a idéia. Alguns anos depois, em idênticas circunstâncias de desalento e tédio, me ocorreu o mesmo desabafo de evasão da 'vida besta'. Desta vez o poema saiu sem esforço, como se já estivesse pronto dentro de mim. Gosto desse poema porque vejo nele, em escorço, toda a minha vida; e também porque parece que nele soube transmitir a tantas outras pessoas a visão e promessa da minha adolescência - essa Pasárgada onde podemos viver pelo sonho o que a vida madrasta não nos quis dar. Não sou arquiteto, como meu pai desejava, não fiz nenhuma casa, mas reconstruí, e 'não como forma imperfeita neste mundo de aparências', uma cidade ilustre, que hoje não é mais a Pasárgada de Ciro e sim a 'minha' Pasárgada" (BANDEIRA, 1990, p. 80). 


\section{SAUDADES DE MELQUISEDEQUE}

Esta manhã gostaria de ter dado ontem um grande passeio àquela praia onde ontem por sinal passei o dia. $\hat{E}$ difícil a vida dos homens, Senhor. Os anjos tinham outras possibilidades e alguns deles foi o que tu sabes. Esta terra não está feita para nós. Mesmo que ela fosse diferente nós quereríamos talvez outra terra, talvez esta onde estamos agora.

Não achas, meu Senhor, que temos braços a mais, dias a mais, complicações a mais?

- p'ra nascer e morrer seria necessário tanto?

Falhamos tantas vezes... (Como os judeus que juraram não comer nem beber até matar Paulo

e apesar disso não o fizeram).

Ê difícil a vida, difícil a morte.

Figura 2. Num exemplar da primeira edição de Aquele grande rio Eufrates, Ruy Belo escreve ao lado do seu poema "Saudades de melquisedeque" a seguinte nota: “No 'Vou-me embora p'ra Pasárgada', Manuel Bandeira diz isto com outra temperatura poética". 
Entretanto, para além de "Saudades de melquisedeque", outro poema de Aquele grande rio Eufrates também chama a atenção pelas ressonâncias a Bandeira, embora desta vez se trate de uma construção alinhada às primeiras marcas estilísticas neste ensaio apresentadas ${ }^{42}$. Temos, assim, com esses dois poemas de AGRE a exemplificação de que as duas formas de lirismo encontradas em Manuel Bandeira também correm de modo paralelo em Ruy Belo desde o início de sua produção poética. Vejamos, então, "Ante um retrato de madame pompadour" na versão da primeira e da segunda edição do livro (grifos nossos, para sublinhar as alterações).
Ai daquelas altivas marquesas
reclinadas nas antigas páginas da história.
Nunca meus olhos viram vossos olhos pela rua, à superfície do tempo.
Quem isolará agora o vosso sorriso dos dias?
Não vos pertencem as mãos que abrem as janelas
e deixam cair dos panos pássaros na rua.
Não repetis o milenário gesto de vir

${ }^{42} \mathrm{E}$ aqui façamos ainda referência a um outro poema, "Das coisas que competem aos poetas", de Boca bilingue, onde esses dois lirismos, ou dois exercícios de estilo (ambos também encontrados em Manuel Bandeira, como mostramos), estão assentes na mesma composição. O poema, que tem como versos iniciais "Nas terras onde os sinos andam pelas ruas / há horas surdas sós e sem cuidados / há mar condicionado ao possível verão", recorda-nos da tempérie tétrica e melancólica de "Saudades de melquisedeque", mas acaba por ser arrematado pelo humor e pela facécia metonímica com "E nas tílias há riscos dos vestidos de retintas raparigas / e o dente resistente número quarenta cheira a Pepsodent" (BELO, 2009, p. 208). Há ainda de entremeio versos como "o gato dorme a trepadeira sobe / o soba grita nunca ninguém sabe / a erva cresce e as crianças morrem", que lembram a forma curta descritiva de composições bandeirianas, como em "Pensão familiar", de Libertinagem. 
pela manhã deixar o lixo à porta.

Vós que antes abríeis os lençóis da aurora, erguidas como as tendas de Salomão

no planalto da nossa admiração, vejo-vos em tardes rubras brilhar sobre um altivo mar de esquecimento.

$\mathrm{Ai}$, que foi feito de todas essas grandes marquesas? ${ }^{43}$

Ai daquelas altivas marquesas nas páginas da história reclinadas

Nunca cruzei na rua os olhos com os vossos à superfície do tempo

Quem hoje isolará dos dias o vosso sorriso?

Não são vossas as mãos que abrem as janelas e deixam cair pássaro na rua dos panos que empregais para limpar o pó Não repetis o milenário gesto de vir pela manhã deixar o lixo à porta Vós que abríeis antes os lençóis da aurora como as tendas de salomão erguidas no planalto da nossa admiração vejo-vos em tardes rubras brilhar sobre um altivo mar de esquecimento Ai que foi feito de todas essas grandes marquesas? ${ }^{44}$

Primeiro, é preciso se dizer que as modificações tornaram o poema mais limpo e mais oculto também; quer dizer, exige-se mais do leitor ao se engendrar versos com construções menos diretas e mais polidas (o que vem a somar à cadência do poema, naturalmente). Por exemplo, quando na segunda versão se omite o adjetivo "antigas" do segundo verso e se cria um novo verso, que passa a ser o oitavo "dos panos que empregais para limpar o pó", lá está a ideia de algo envelhecido (e de que se precisa retirar o pó, ideia então acrescida), sem no entanto

${ }^{43}$ BELO, 1961, p. 102, sublinhado nosso.

${ }^{44}$ BELO, 1996, p. 116, sublinhado nosso. 
se utilizar a obviedade de "antigas páginas da história" para dizê-lo. Até mesmo quando se evita a repetição da palavra "olhos" em "Nunca meus olhos viram vossos olhos pela rua" a linguagem poética é melhor manejada, tornando o verso mais fluido ${ }^{45}$.

As outras modificações que constatamos servem, não obstante, para fazer sutis alterações de tempo, como quando em "Vós que antes abríeis os lençóis da aurora" o advérbio "antes", ao anteceder o verbo, está relacionado à noção de "antigamente" e, portanto, de um espaço de tempo mais longínquo, e na alteração em que é colocado depois do verbo acaba por inscrever a ideia de previdência ou precedência do gesto de se abrir os lençóis da aurora, aproximando esse gesto temporalmente. Outras modificações temporais estão em "Quem isolará agora o vosso sorriso dos dias", que perde a especificidade do presente trazida pelo advérbio e corroborada pela construção direta com o objeto indireto "dos dias", e ganha a noção de atualidade (amplia-se a perspectiva temporal) com o advérbio "hoje" e a aproximação de "dos dias", elucidando o ruído que havia antes. Na nova versão, naturaliza-se ainda a fala do eu-lírico preterindo "Não vos pertencem as mãos" por "Não são vossas as mãos" (a ideia de pertencimento das mãos desfamiliariza a própria evidência da pertença das mãos) e corrige-se um erro de conjugação do adjetivo "erguidas", que na primeira versão deveria estar no masculino por se referir a "os lençóis da aurora" e que passa para o final do verso seguinte com o desígnio de, então, ser conjugado com "as tendas de salomão", como parece ter sido o intuito desde o início.

${ }^{45}$ Como se trata de um poema escrito em 1959 e publicado no primeiro livro de Ruy Belo, é natural que mais de uma década depois tenha havido um conspícuo aprimoramento do manejo da linguagem poética. 
Para mais, o poema brinca com todo o universo simbólico de "marquesa". Leva-nos logo a pensar, inclusive pela linguagem pomposa adotada (motivada pelo pronome de tratamento vós e pelo recursivo pronome possessivo vosso, bem como pelo rebuscamento das imagens poéticas - tais como "planalto da nossa admiração", , "tardes rubras", "lençóis da aurora" - que nos remetem a toda uma tradição do século XIX), nas marquesas enquanto membros da aristocracia "nas páginas [antigas] da história reclinadas". O próprio título assim o denuncia, fazendo referência a Jeanne-Antoinette Poisson, mais conhecida como Madame de Pompadour ou Marquesa de Pompadour (veja que o poeta opta por usar no título a palavra madame e não marquesa, sendo que esta vem a ser a palavra mais cara ao poema), amante do Rei Luís XV da França, considerada uma das mulheres mais emblemáticas do século XVIII ${ }^{46}$.

Aliás, mais do que fazer referência a Madame Pompadour, o nome do poema faz menção a um retrato dela e ao eu-lírico diante dele. Neste detalhe reside toda a perspicácia com a construção de sentido, uma vez que se procurarmos as várias pinturas ${ }^{47}$ que existem de Pompadour, veremos que em muitas

${ }^{46}$ Conhecida por sua grande influência em Versalhes, tendo permissão do Rei para conceder ou não audiências com ele ou permitir favores em troca de outros. Além de influenciar as decisões reais, também estava por trás de vários projetos comerciais ou de industrialização, inclusive sendo responsável por incentivar a fundação da importante fábrica de porcelanas de Sèvres, que existe até hoje (Cf. GOODMAN, 2000).

47 Em The portraits of Madame de Pompadour: celebrating the femme savante, de Elise Goodman, estão catalogadas quinze pinturas e quatro desenhos de Madame de Pompadour, uma das mulheres, ou se quisermos femme savante, portanto, mais pintadas na França do século XVIII. Dentre os retratistas, destacam-se François Boucher, FrançoisHubert Drouais, François Guérin, Jean-Marc Nattier, Charles-André van Loo, Maurice-Quentin de La Tour e Jean-Etienne Liotard. 
ela está deitada numa marquesa (ou canapé): tanto na obra de François Boucher, Portrait de Madame de Pompadour, por exemplo, de 1756, que atualmente integra o acervo de Alte Pinakothek, em Munique, quanto no retrato Madame de Pompadour à son métier à broder, feito entre 1763-1764 por François-Hubert Drouais, e que hoje está exposto no National Gallery, em Londres, como também no famoso Sultane (représentant Mme de Pompadour), em que Charles-André van Loo retrata a marquesa, em 1747, com vestimentas turcas sendo servida por uma criada, num ambiente com decoração oriental, num dos quadros que se tornou referência do início das influências do orientalismo na arte francesa e que hoje pertence ao Musée des Arts Décoratifs, em Paris.

Quer dizer, de uma forma ou de outra, a marquesa está lá: a aristocrata e a outra, a peça de mobiliário que tanto denuncia o estilo de uma época. E é o último verso que cria a ambiguidade, delineada pelo emprego do recurso onomatopeico "ai". Ele abre o poema atuando com um valor evocativo para chamar a atenção para as marquesas que se foram ficando perdidas, esquecidas na história (e as marquesas, não obstante, também podem funcionar aqui em valor metonímico, representando toda uma reflexão sobre a passagem do tempo e as transformações dos períodos históricos e dos sistemas hierárquicos); mas não por acaso "ai" é novamente empregado no início do último verso, só que desta vez com um sentido expressamente de interjeição - e na primeira versão do poema isto fica ainda mais evidente, uma vez que só o segundo "ai" é seguido de vírgula, para isolar e enfatizar, fortalecer a forma expressiva -, criando uma espontaneidade de momento com caráter saudosista, tanto pelo desvanecer histórico dessas figuras ou, numa segunda interpretação, pelo desaparecimento de canapés tão estilosos (aqui, seria como se fosse uma observação repentina do eulírico, que no final do seu momento de reflexão complacente 
ou de contemplação repara no canapé). Mas, ao fim e a cabo, a "marquesa", independente do significado adotado na interpretação do último verso, está sempre atrelada à passagem do tempo e ao esquecimento que oblitera da história nichos de existência (seja de pessoas, seja de objetos).

A propósito, observemos que esse lirismo voltado para um humor refinado, caracterizado pela eminência de uma situação inesperada ou pela surpresa, e que confere importância crucial ao remate numa brincadeira com a própria forma de composição lírica, é uma das características mais presentes não só em Manuel Bandeira mas em vários outros poetas da primeira geração do modernismo brasileiro. Vejamos um poema de Oswald de Andrade, publicado em seu primeiro livro, PauBrasil, de 1925, e outro de Ruy Belo, publicado 45 anos depois em Homem de palavra(s).

\section{A laçada \\ O Bento caiu como um touro \\ No terreiro \\ E o médico veio de Chevrolé ${ }^{48}$}

${ }^{48}$ Vide o detalhe de "chevrolé" escrito da maneira como se fala em português, circunscrevendo a importância da coloquialidade na composição poética. Lembremos ainda que, três anos depois, em 1928, Fernando Pessoa escreveria sob o pseudônimo de Álvaro de Campos: "Ao volante do Chevrolet pela estrada de Sintra, / Ao luar e ao sonho, na estrada deserta, / Sozinho guio, guio quase devagar [...]" (PESSOA, 1993, p. 252). E em ressonância a este poema, por sua vez, ainda encontramos em Homem de palavra(s), no poema "A autêntica estação", os versos: "É verão. Vou pela estrada de sintra / por sinal pouco misteriosa à luz do dia / ao volante de um carro que não é um Chevrolet" (BELO, 1997, p. 119). Nos dois primeiros casos, o metônimo Chevrolet cria a particularidade de anuir ao cotidiano através da popularização recente de uma marca de automóveis; já em 
Trazendo o prognóstico

E toda a minha infância nos olhos ${ }^{49}$

\section{Um prato de sopa}

Um prato de sopa um humilde prato de sopa comovo-me ao vê-lo no dia de festa e entro dentro da sopa e sou comido por mim próprio com lágrimas nos olhos ${ }^{50}$

Notemos como os dois poemas emergem de uma situação inusitada e toda uma tradição lírica voltada para o apelo emocional vai sendo desmontada com a estranheza e a desfamiliarização, que não obstante acabam por ser atenuadas pelo verso final onde o próprio tom lírico é apelativo ("infância nos olhos", "lágrimas nos olhos"). Para mais, muitas vezes poemas nesses vieses retratam pedaços de vida, que não só delineiam recortes no tempo mas vidas fragmentadas, gotejadas dia a dia sem que se consiga ver mais do que os seus bocados, numa sapiente estrutura de criação que não absorve a convencional causalidade genética, onde a metonímia funciona como causa e a metáfora como efeito, mas funciona enquanto causalidade teleológica, na qual a metáfora é o fim e a metonímia o meio para esse fim $^{51}$.

É nesta perspectiva metonímica que encontramos também em Homem de palavra(s) o poema "Necrologia", que nos leva a pensar em outro nome do modernismo brasileiro, Carlos Drummond de Andrade.

Ruy Belo, o que vemos é uma reação à leitura do poema pessoano.

${ }^{49}$ ANDRADE, 2003, p. 27.

${ }^{50}$ BELO, 1997, p. 58.

${ }^{51}$ Cf. DE MAN, 1984, p. 68. 


\section{Necrologia}

Portugal tem nove milhões de habitantes

Lisboa talvez tenha um milhão

Nada disto me pode consolar bem sei

Morreu António Gião

Eu não o conhecia nunca o conhecerei ${ }^{52}$

\section{A bruxa}

Nesta cidade do Rio,

de dois milhões de habitantes,

estou sozinho no quarto,

estou sozinho na América.

Estarei mesmo sozinho?

Ainda há pouco um ruído anunciou vida ao meu lado.

Certo não é vida humana, mas é vida. E sinto a bruxa presa na zona de luz.

De dois milhões de habitantes!

E nem precisava tanto...

Precisava de um amigo, desses calados, distantes, que lêem verso de Horácio

mas secretamente influem na vida, no amor, na carne. $[\ldots]^{53}$

Observemos como a técnica adotada no início do poema de Ruy Belo é a mesma usada por Drummond. Primeiro localiza-se espacialmente ("Portugal" no primeiro caso e "Rio"

52 BELO, 1997, p. 57.

${ }^{53}$ ANDRADE, 1988, p. 78. 
no segundo) e depois demograficamente ("nove milhões de habitantes", "dois milhões de habitantes", respectivamente), utilizando a grandeza do número de habitantes para provocar a sensação de amplitude. Logo em seguida essa dimensão é afunilada numa reflexão sobre o indivíduo, e sobre o individual. O sentimento de se estar no mundo não deixa de ser encontrado nos dois poemas, mas em Drummond o rumo que o poema segue distende sobre uma reflexão existencial, enquanto em Ruy Belo o poema é, mais uma vez, revestido por aquele ar chistoso ou pelo humor enternecido que encontramos em certos poemas belianos associados a Manuel Bandeira.

Assim, distante do peso existencial e tétrico do gauche drummondiano, a "Necrologia" de Ruy Belo (não só como poema, mas inclusive enquanto prática exercida na composição), pelo contrário, tem um invólucro anedótico, mas que não significa distanciamento das questões sobre a existência, afinal, o ar de indiferença com que o poema de Ruy Belo acaba já é, por ironia, sintoma do incômodo causado pelas reflexões sobre a própria existência, e nela a fatalidade da morte - e a morte de uma pessoa pode abalar mundos, ou mesmo a morte de uma pessoa diminui a existência de outra, ou dobra sinos, como diria o pastor e poeta inglês John Donne, que com a sua poesia metafísica do século XVII em muito influenciou várias gerações de escritores e artistas da primeira metade do século $X X^{54}$, não

${ }^{54}$ Ideias de John Donne como a de que "quando morre um homem, morremos todos, pois somos parte da humanidade", presente na obra Poems on several occasions (em português, traduzida por Meditações), teve grande reverberação em diversos meios artísticos em meados do século XX para falar sobre a condição humana diante de uma aflorada conjuntura bélica. A famosa expressão "for whom the bell tolls", por exemplo, foi adotada em 1940 como o título de um dos principais romances de Ernest Hemingway. Três anos depois estreia um filme homônimo dirigido por Sam Wood e com os mais 
obstante o próprio Ruy Belo, como vemos em poemas como "Na morte de georges braque" e "Das coisas que competem aos poetas".

Outro poema de Homem de palavra(s) cujo núcleo simbólico também reconhecemos em Carlos Drummond de Andrade é "José o homem dos sonhos". Nele, Ruy Belo vai, digamos, preencher ou enxertar o "José" de Drummond com um dos mais tenros de seus desejos em $H P$, que é assomar um deus que "anda à beira de água calça arregaçada / como um homem se deita como um homem se levanta" 55 , como lemos no poema "Orla marítima", sob o mesmo sol que passa a incidir ainda mais vigorosamente nos livros seguintes, tal constatamos em "E neste coração ambicioso / sozinho como um homem morre cristo" em "A flor da solidão", de Transporte no tempo. Deus como a mais redonda boca para o homem do homem, parafraseando outros versos, desta vez de "Efeitos secundários", em Boca bilingue, onde a ideia era ainda embrionária. E assim, também alvitre destas insurgências, lá, ou melhor, aqui está José, então josé.

\section{José o homem dos sonhos}

Que nome dar ao poeta

esse ser dos espantos medonhos?

Um só encontro próprio e justo:

o de josé o homem dos sonhos

Eu canto os pássaros e as árvores

Mas uns e outros nos versos ponho-os

Quem é que canta sem condição?

É josé o homem dos sonhos

importantes atores da época, Gary Cooper e Ingrid Bergman. "Por quem os sinos dobram" é também o nome do nono álbum de Raul Seixas, lançado em 1979.

${ }^{55}$ BELO, 2009, p. 321.

${ }^{56}$ BELO, 2009, p. 378. 
Deus põe e o homem dispõe

E aquele que ao longo da vereda vem homem sem pai e sem mãe

homem a quem a própria dor não dói bíblico no nome e a comer medronhos só pode ser josé o homem dos sonhos ${ }^{57}$

\section{E em Drummond:}

José

E agora, José?

A festa acabou, a luz apagou, o povo sumiu, a noite esfriou, e agora, José? e agora, você? você que é sem nome, que zomba dos outros, você que faz versos, que ama, protesta? e agora, José?<smiles>C1=C[SiH2]1</smiles>

Se você gritasse, se você gemesse, se você tocasse a valsa vienense, se você dormisse, se você cansasse, se você morresse... Mas você não morre, você é duro, José!

${ }^{57}$ BELO, 1997, p. 110. 


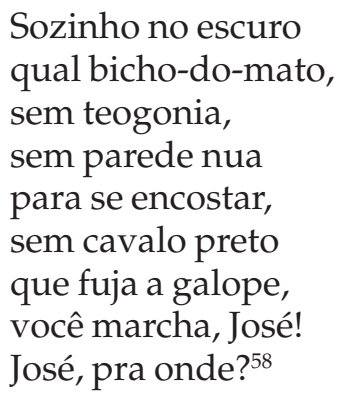

Do José bíblico, nome de vários personagens importantes do livro sagrado ${ }^{59}$, ao José nome popular, nome de homem comum, que de tão comum não dificilmente representa a perda de individualidade. O Zé. O Zé da esquina, o Zé ninguém, o Zé mané. "homem sem pai e sem mãe", como diz Ruy Belo. E tanto na composição de Ruy Belo quanto na de Drummond é com todos esses Josés-Zés que se identifica o eu-lírico (o poeta, o "ser dos espantos medonhos" ou o "você que faz versos"), em poemas onde ele tanto dialoga tendo José como um terceiro (indiretamente em Ruy Belo e diretamente em Drummond) quanto tomando José como uma manifestação de si mesmo. Mas José "o homem dos sonhos" não deixa de ser uma resposta de esperança ao José de Drummond, onde "tudo acabou / e tudo fugiu / e tudo mofou", que marcha sem saber para onde. José, que em sua etimologia em hebraico significa "aquele que acrescenta", é também aquele que multiplica, aquele que se multiplica - afinal, são muitos josés que cabem num só josé, quer o de Ruy Belo, quer o de Drummond, a diferença é que no deste a festa acabou, no daquele José continua a cantar mesmo sem condição, como lemos na segunda estrofe.

Outras ressonâncias de Carlos Drummond de Andrade em Ruy Belo, não obstante somadas às influências de Manuel

${ }^{58}$ ANDRADE, 1988, p. 88.

${ }^{59}$ E por ser um nome tão comum na Bíblia acabou por ser popularizado. 
Bandeira, podem ainda ser observadas no poema "To helena". Trata-se, no entanto, de um poema incluído no livro seguinte, Transporte no tempo, de 1973, evidenciando mais uma vez as pujantes marcas da atmosfera em que se moveu Homem de palavra(s) e a sua reverberação nas obras subsequentes. Encontramos marcas da construção de "To helena" em Manuel Bandeira: análise e interpretação literária (Figura 3 e Figura 4), de Emanuel de Moraes, livro que Ruy Belo estudou atentamente (vê-se pela marginália) e onde marcou o seguinte trecho: "Êsse é um dos recursos poéticos mais sensíveis de Manuel Bandeira: o advérbio de modo terminado em mente. [...] o certo é que êsse sufixo adverbial dá uma valorização poética extraordinária à frase, transmitindo-lhe tôda a musicalidade ${ }^{\prime \prime 60}$. Podemos ainda alongar a citação, distendendo a análise:

Usam, magnificamente, êsse recurso prosadores como Machado de Assis, Ruy Barbosa e Euclides da Cunha. E, pela coincidência sonora com o francês, podemos exemplificar ainda com Baudelaire e Mallarmé.

A respeito dos efeitos poéticos dêsses advérbios em mente, tendo em vista êsses dois poetas, escreve Jacques Scherer: "Mallarmé aime les longs et lourds adverbes de manière; il en emploie, ou il en crée, d'assez imprévus... Dans Baudelaire également, le jeune Maurice Barrès évoquait, le 5 novembre 1884 , ' 1 'angoisse des adverbes très longs quis suspendent la phrase'. Chez Mallarmé ces adverbes sont interessants, non seulement par leur fréquence et leur forme parfois étrange, mais aussi parce qu'ils sont chargés d'intentions. Il donne souvent à ces lourdes adverbes un sens plus riche e plus nuancé qu'il n'appartient d'ordinaire à un mot invariable. On sent toute la valeur évocatrice et musicale à la fois de l'adverbe...".

São êsses também os efeitos que Manuel Bandeira tira dos advérbios em mente ${ }^{61}$.

${ }^{60}$ MORAES, 1962, p. 27.

${ }^{61}$ MORAES, 1962, p. 27 e 28. 
E aqui parafraseamos esta última frase: são esses também os efeitos que Ruy Belo tira dos advérbios terminados em mente, como vemos em "To helena", criando uma suspeição, ou mesmo algo inesperado, pela própria recursividade dos modalizadores em mente, que suspendem o verso não só ocasionando estranheza bem como sutilmente indiciando as intenções - "os interesses quanto às tarefas da enunciação"62, como diria José Carlos de Azeredo - que são espargidas no poema e nele veladas.

\section{To helena}

Acabo de inventar um novo advérbio: helenamente A maneira mais triste de se estar contente a de estar mais sozinho em meio de mais gente de mais tarde saber alguma coisa antecipadamente Emotiva atitude de quem age friamente inalterável forma de se ser sempre diferente maneira mais complexa de viver mais simplesmente de ser-se o mesmo sempre e ser surpreendente de estar num sítio tanto mais se mais ausente e mais ausente estar se mais presente de mais perto se estar se mais distante de sentir mais o frio em tempo quente [...]

Quando helena recusa é que consente se tão pouco perdoa é por ser indulgente baixa os olhos se quer ser insolente Ninguém é tão inconscientemente consciente tão inconsequentemente consequente Se em tantos dons abunda é por ser indigente e só convence assim por não ser muito convincente e melhor fundamenta o mais insubsistente

${ }^{62}$ AZEREDO apud LEAL, 2012, s/p. 
Acabo de inventar um novo advérbio: helenamente

$\mathrm{O}$ mar a terra o fumo a pedra simultaneamente ${ }^{63}$

Ruy Belo consegue utilizar ${ }^{64}$ com sutileza, assim, semantemas densos e dar-lhes uma riqueza de sentido, criando um valor musical evocativo que nos faz perceber o elemento modelizador tanto em sua destreza conteudística ou ideológica quanto em toda a sua contribuição à linguagem poética, sem que uma diretriz se sobreponha à outra. O poeta emprega a técnica com cabal consciência de que os modalizadores terminados em mente não são elementos textuais diretamente ligados a um ou outro termo (um advérbio que, do ponto de vista sintático, modifica um verbo, um adjetivo ou outro advérbio,

${ }^{63}$ BELO, 2009, pp. 427 e 428.

${ }^{64}$ E lembremos aqui que o poeta, numa entrevista de 1968, depois de recitar os quatro primeiros versos de "Mar. Manhã" ("Suavemente grande avança / Cheia de sol a onda do mar; / Pausadamente se balança, / E desce como a descansar."), de Fernando Pessoa, diz: "É sabido que a poética actual tem lutado contra os adjectivos e os advérbios, vocábulos respectivamente secundários e terciários, na classificação de Jespersen" (BELO, 2002, p. 24). E continua a falar como Pessoa consegue, mesmo num "texto cheio de defeitos", uma "alta temperatura", como consegue, tal como disse Óscar Lopes da poesia beliana, provocar "um sismo vivificante no senso comum da realidade" (BELO, 2002, p. 24). Com essas associações feitas por Ruy Belo, percebe-se que está implícito em seu discurso que os modalizadores são de grande relevo neste processo de abalo sísmico da realidade de que a poesia é capaz. 


\section{mete duses.}

desde os dezoito anos, habituado a ela como cândida amiga, sem desejo de imortalidade, vivendo mum cotidiano morrer, apenas preocupado em que ela não o levasse sem que nada houvesse feito, mas achando, afinal, com o avancar da idade e com sua obra realizada, que ela poderia vir.

Aqui e ali, em seus poemas, encontra-se essa intimidade com a morte e até êsse "agora a morte pode vir" de suas memórias, numa de suas mais notáveis criaçes: Consoada.

Todavia, não só o tema da morte se destaca em sua obra. Outros sobressaem, como o do amor, sobretudo o amor erótico, e o "da vida bêsta". Ora isolados, ora formando um só poema. Por vêzes apontando o seu desejo de viver, amar e ser amado, outras o seu desencanto, ou sua vontade de morrer.

Mas em face dos problemas da vida, do amor e da morte, sobreleva a satisfacáo imensa de se haver realizado como poeta.

Essa é a idéia geral que fazemos da obra de Manuel Bandeira, poeta que bem é tudo aquilo que a seu respeito disse Mário de Andrade: "Um escritor culto, um esteta, que sabe o dinamismo de um ritmo, o segrêdo de adequaçáo de uma forma ao seu conterido, o valor da expressão lingüistica exata, e o perigo de uma palavra em falso, capaz de sacrificar uma mensagem."

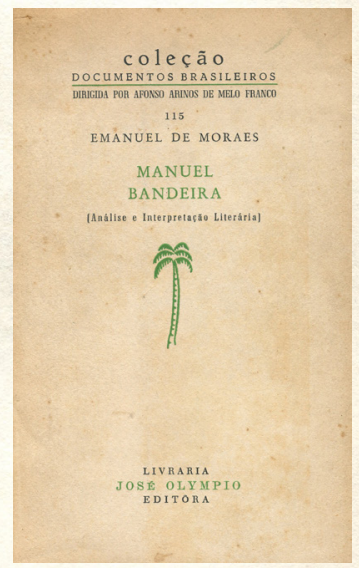

É tal o poder da redondilha de transmitir lirismo que, em muitas composicões populares ou literárias, a simples presença dêsse metro constitui 0 único elemento de construção poética e suficiente para manter o clima encantatório do conjunto, se bem que os detalhes demonstrem certa fraqueza da composição ou mesmo o engano da primeira leitura.

Além do mais é o septassilabo um verso fácil para ser manejado sintaticamente, devido, justamente, a ser o idiomático, havendo uma perfeita combinação entre a língua e a metrificação, donde os verdadeiros milagres que a redondilha às vêzes consegue.

Manuel Bandeira, é verdade, em "Cartas de Meu Avô", não partiu exclusivamente da linguagem comum. 0 poema divide-se, sob êsse aspecto, em três partes bem distintas. A primeira, formada pelas duas estrofes iniciais; a segunda, pelo corpo do poema; a terceira, pelas duas quadras finais: a penúltima quase uma repetição da primeira e a última uma integral repetição da segunda.

Nessas estrofes extremas há, nitidamente, maior vivacidade rítmica, e a linguagem é lírica. E 0 poeta, disso consciente, enquadra o poema entre êsses dois momentos, um dos recursos que usa para transmitir ritmo poético às estrofes em que a linguagem poderia conduzir à destruição da poesia. E enquadra a composição entre essas estrofes paralelas tão-sòmente com êsse objetivo, porquanto nenhuma fôrma fixa o dirigiu. A percepção do ritmo do poema foi que determinou essa solução.

A diferença existente na primeira e penúltima quadras resultou da necessidade de modificação da paisagem e do teor da chuva pelo decurso do tempo. Mas o poeta mantém os processos rítmicos apesar da substituição das palavras. A assonância do ditongo ai, fazendo um triângulo com as rimas, é mantida. Repete a tríade de adjetivos do segundo verso, quer em relação a tarde como a noite, dês que, apesar do decurso do tempo, o ambiente não se modificara. E a substituição do substantivo gôtas por pingos, com que expressa a evolução da chuva, não altera o processo aliterativo.

É nessas estrofes que também se encontra 0 maior apoio rítmico do poema: a palavra monòtonamente.

Êsse é um dos recursos poéticos mais sensíveis de Manuel Bandeira: 0 advérbio de modo terminado em mente.

Malgrado o opinamento, sem dúvida apressado, de Charles Bailly, que certamente não terá meditado tendo em vista as possibilidades rítmicas dêsse sufixo e que escreveu: "Les adverbes en ment sont une formation en apparence très vivante et productive; en fait, celle-ci est liée à plusieurs conditions qui la gênent et lapauvrissent", qualificando de manuel bandeira 27

Figura 3. Fac-símile da última página da Introdução do livro Manuel Bandeira: análise e interpretação literária (capa na imagem em detalhe). Ruy Belo corrige a citação feita por Emanuel de Moraes, salientando que Manuel Bandeira "não diz isto, mas sim 'O meu dia foi bom, pode a noite descer"'.

Figura 4. Página do livro de Emanuel de Moraes onde se faz a primeira menção ao uso de advérbios terminados em mente na poesia de Bandeira. Ruy Belo marca o trecho. 
por exemplo), mas sim a toda uma sentença. A função do sufixo mente acaba, assim, por estar mais associada à semântica do que propriamente à formação de palavras em classes gramaticais, e então semanticamente falando, nesses casos se torna difícil dissociar um adjetivo de um advérbio, como bem constatamos no poema acima, já que o advérbio em mente é visto diversas vezes como um modalizador pelo fato de servir como qualificador de algo, da mesma forma que um adjetivo qualifica um substantivo ${ }^{65}$.

Quer dizer, a modalização dá um direcionamento argumentativo que vai sendo paulatinamente construído no poema (quem é essa helena para quem o eu-lírico está? Afinal, usa-se a expressão "to" ${ }^{\prime 66}$ no título) e, como esses elementos modeladores têm em sua função discursiva o poder de incidir o seu significado sobre todo um verso, como dissemos há pouco, muito do valor de modalizador desses elementos encontra-se no processo de formação deles. É aqui que se soma a relevância dos neologismos - reparemos que o primeiro verso de "To helena" é "Acabo de inventar um novo advérbio: helenamente" - e se alude a uma fase nominal, como assim se convencionou na poesia drummondiana ${ }^{67}$, com o uso intensivo de figuras

${ }^{65}$ Cf. LEAL, 2012, s/p.

${ }^{66}$ A abreviação de "estou", "to", inclusive é muito utilizada coloquialmente na língua portuguesa falada no Brasil. No entanto, outra fonte de interpretação possível é que o título "To helena" esteja relacionado com o famoso poema "To Helen" ("Para Helena", em português), de Edgar Allan Poe, publicado pela primeira vez em Poems of Edgar A. Poe, em 1831, e numa segunda versão em 1845. Nessa composição, Poe celebra o poder maternal da mulher utilizando como imagem a Helena de Troia e várias referências da cultura clássica, sendo os versos 9 e 10 ("To the glory that was Greece, / And the grandeur that was Rome") dois dos mais citados de sua obra.

${ }_{67}$ Recordemos que, mesmo mais de duas décadas depois da publicação de Lição das coisas, em meados dos anos 80 encontramos ainda um Drummond que assina poemas como "Salário", em Amar 
de linguagem fônicas, sobretudo aliterações, assonâncias e rimas externas terminadas com o mesmo sufixo, num processo de composição poética em que há a coisificação da palavra "Sobre um simples significante"68, para utilizar o título de um outro poema de Ruy Belo no mesmo livro e que corrobora a recorrência desta técnica, dessa vez com a última palavra de cada verso tendo que obrigatoriamente conter o sufixo al. De fato, trata-se de um poeta que conhece " [...] as coisas e as palavras de maneira oficial / que como linguista as trato de igual para igual / travo afinal inexorável batalha campal"69. Ou, então, um poeta que, como revela "Primeiro poema de Madrid", sabe a "construção linguística difícil aparentemente", e que assume "que em troca da vida e do triunfo me tornei teu ínfimo cultor", declarando-se à poesia que "por todos se faça", "por todos se destine"

E por falar em cultor, em Transporte no tempo encontramos ainda um poema que pode ser associado a outro poeta brasileiro, dessa vez àquele que ficou conhecido no modernismo brasileiro como o (es)cultor da palavra, João Cabral de Melo Neto. Em “Os

se aprende amando, onde persiste numa composição onde a palavra final de cada verso termina em ário.

${ }^{68}$ É muito importante aqui que se diga que a diferença entre "To helena" e "Sobre um simples significante" reside que, neste, podemos encontrar o que Osvaldo Silvestre chama de processo em que "o ludismo em torno do significante se alimenta por vezes de si mesmo" (SILVESTRE, 1997, p. 19), enquanto naquele vemos que "Com Ruy Belo, de novo poesia e versificação voltam a andar de braço dado, no que, entre outras coisas, é uma voluntária cedência aos prazeres da retórica e sobretudo da prosódia, bem longe do austero racionalismo ou minimalismo de efeitos característicos da mais significante falange do modernismo tardio" (SILVESTRE, 1997, p. 19).

${ }^{69}$ BELO, 2009, p. 400.

${ }^{70}$ BELO, 2009, p. 398. 
galos", Ruy Belo ${ }^{71}$ catalisa o núcleo simbólico do famigerado poema "Tecendo a manhã", de A educação pela pedra, de 1966, e nele imprime as suas marcas de absorção da naturalidade, da simplicidade e da cotidianidade da vida, características, aliás, que podemos ir buscar lá atrás, em convergência com Manuel Bandeira. Enquanto "os galos tilintam na manhã / numa múltipla voz", também "há já pão mole e lombo assado nas primeiras lojas" e "era ainda vivo o carlos". E apesar de haver no poema beliano um cuidadoso ritmo em versilibrismo, distante da obsessão de João Cabral pela métrica, em ambas as composições os galos são "o símbolo da voz", "moem os nós da voz", "para que a manhã, desde uma teia tênue, / se vá tecendo [...]". O "grito" (em vez de canto, palavra que seria mais usual) do galo de João Cabral também atrita como o pão a "quebrar nos dentes" que Ruy Belo descreve.

Mas enquanto este poeta, já no fim do poema, com o seu último verso em polissíndeto "Ó galos ó manhã ó vida ó nada", cede ao lirismo enfadonho (ou ao "gosto da tristeza"72, como Adolfo Casais Monteiro aponta em Manuel Bandeira), como quem fecha a janela e as cortinas depois de ter presenciado o "[...] mais puro amanhecer / que touca o céu da mais fina das fímbrias"73, em "Tecendo a manhã", ao contrário, há uma abertura para a luz, que mesmo "luz balão", luz que voa para longe, existe enquanto fissura que permite que a manhã sempre rompa e propicie um novo dia. Há esperança em João Cabral (observemos expressões como "entre todos", "entrem todos", "para todos", numa manhã "que plana livre de armação"74),

\footnotetext{
${ }^{71}$ Vale ressalvar que Ruy Belo chegou a conhecer João Cabral de Melo Neto em 1968 na cidade do Fundão, na altura em que o brasileiro ainda residia em Portugal, exercendo o cargo de diplomata no Porto. 72 MONTEIRO, 1968, p. XXIV.

${ }^{73}$ BELO, 2009, p. 447.

${ }^{74}$ MELO NETO, 1997, p. 15.
} 
com os galos unidos na composição solidária e gradativa da manhã, enquanto em Ruy Belo "Os galos são os rígidos e estritos observantes / do ritual restrito da destruição / quando de crista erguida uns aos outros passam / a vida única vítima final a imolar"75.

Certo é que, lendo esses versos acima, atentamos ainda para refletir que os dois poemas não apenas dão sentido a uma espécie de teia coletiva (e uma reflexão sobre a tessitura social a partir dela) dos anônimos galos que tecem (no poema de João Cabral) ou que tilintam (no poema de Ruy Belo). Tanto um como outro podem ser vistos como uma expressão forte do artesanato poético a revelar um outro trabalho artesanal, que é o da emenda de sons dos próprios galos. Quer dizer, são poemas metalinguísticos também, que, no caso do poema cabralino, descreve a disposição sintática apoiada em mecanismos variados de coesão e remontagem de estruturas, ao passo que na composição beliana a própria condição do poeta é o tecido para o poema, o poeta como "esses tenores sapientes saborosos exigentes / que têm na garganta a música difícil / que precede o abrir do novo dia"76. E os dois versos anteriores a estes são reveladores, quando essa nuance é tenuamente denunciada: "Só quando se consome a vida se mantém / e sei agora como o sabem bem"77. Como o sabem bem os galos, como o sabem bem os poetas.

Mais adiante em Transporte no tempo, essa motriz metalinguística é desenvolvida em “O urogalo”. À ressonância de "galo" (que continua a ecoar), agora trata-se de apenas um, e de uma ave rara, que vive "solitária e livre", "solitária e triste", numa solidão e liberdade que "podem custar a vida àquele que vive", mas que "morre se não canta" (como o poeta

\footnotetext{
${ }^{75}$ BELO, 2009, p. 447.

${ }^{76}$ BELO, 2009, p. 447.

77 BELO, 2009, p. 649.
} 
que morre se não escreve), "porque quando canta leva a cabeça erguida / e apenas o perigo dá sentido à vida"78. Contudo, em "O urogalo", apesar de o núcleo simbólico está bem mais afastado de "Tecendo a manhã" do que de "Os galos" (onde podemos observar que é de intenção manifesta a correlação), o desfecho é, tal como no poema de João Cabral, mais aberto ao mundo: "e que levante o canto em liberdade / e que ao cantar a solidão seja cidade $^{\prime 79}$, lemos no fim do poema beliano. A cidade é a armação onde, mais do que uma tenda ou told $0^{80}$, se aprende que "uma andorinha só não faz verão", como se diz popularmente, ou como parafraseou João Cabral, "Um galo sozinho não tece uma manhã: / ele precisará sempre de outros galos" 1 .

No livro seguinte de poemas diversos ${ }^{82}$, Toda a terra, de 1976, encontramos ainda outro poema beliano que partilha de uma esfera convergente com a de João Cabral de Melo Neto, só que desta vez em Morte e vida severina. Estamos a nos referir à "Canção do cavador" 83 , poema que parece, de fato, cumprir todo o ciclo de uma vida severina e de uma morte severina, nome próprio muitas vezes associado no Brasil a pessoas de classe social desfavorecida e que João Cabral transformou em adjetivo para caracterizar todo o sofrimento vivido pelo sertanejo. Assim

\footnotetext{
${ }^{78}$ BELO, 2009, p. 650.

${ }^{79}$ BELO, 2009, p. 650.

${ }^{80}$ Estas palavras em itálico estão em "Tecendo a manhã'.

${ }^{81}$ MELO NETO, 1997, p. 15.
}

${ }^{82}$ Antes, em 1974, há a publicação de $A$ margem da alegria, composto por um único poema e sobre o qual trataremos mais adiante.

${ }^{83}$ Aqui é importante lembrar que o termo "cavador" é extraído do campo simbólico que ficou aludido a Manuel Alves (1845-1901), português repentista e analfabeto, a quem o jornalista e escritor Thomaz da Fonseca apelidou de "poeta cavador" ao compilar, no início do século XX, os versos do mecânico no volume "Versos dum Cavador». Não obstante, encontramos dois exemplares da $5^{\text {a }}$ edição, realizada pela Cisial em 1956, na biblioteca de Ruy Belo. 
como na obra cabralina, que relata a dura trajetória de um retirante nordestino que migra do sertão para a cidade em busca de melhores condições de vida - obra que denuncia em parte $o$ que foi o processo de urbanização do Brasil e os deslocamentos demográficos na primeira metade do século XX -, o cavador de Ruy Belo também teve que sair de sua terra: "A terra deixou de dar teve de emigrar / e embora estar fora lhe doa a tudo ele se afeiçoa" ${ }^{\prime 4}$. O poema faz alusão, por sua vez, à intensa emigração portuguesa que houve nos anos 60 e 70 para outros países europeus, sobretudo para a França, a Alemanha e a Suíça ${ }^{85}$. Um cavador que, apesar de encontrar trabalho no exterior, não é só um cavador do exterior: continuará sempre a ser filho da terra que o rejeitou e, por isso, o verso "Não há cavador só do

${ }^{84}$ BELO, 2000, p. 54.

${ }^{85}$ Em Portugal dos anos 60 e 70, a agricultura continuava a ser um setor tecnicamente atrasado, que sofria os efeitos de uma deficiente distribuição de terras e do êxodo da população rural para os centros urbanos. A incapacidade de absorção de outros setores, entretanto, foi um dos principais fatores que levou essa mão de obra a procurar novas oportunidades no exterior. Alguns países da Europa, como a França, a Alemanha e a Suíça, que no pós-guerra conheceram uma fase de prosperidade econômica e precisavam de mão de obra, atraíram milhares de portugueses, que aí procuraram vantajosas condições salariais e uma melhoria da qualidade de vida. Outro ponto fundamental da análise desse fenômeno de migração é a situação política do país. Muitos cidadãos procuravam fugir não só às condições de pobreza mas à Guerra Colonial e à forte repressão política desencadeada pelo regime salazarista. Aliás, este último é um dos motivos de relevo que incentivaram o próprio Ruy Belo a emigrar, vivendo como leitor em Madrid de 1971 a 1977. Não havia completado um ano de seu regresso a Portugal quando ele faleceu. (cf. «Emigração Maciça dos Anos 60». Infopédia [Em linha]. Porto: Porto Editora, 2003-2013. Acesso em: 13/12/2013. Disponível em: <URL: http:/ / www.infopedia. pt/\$emigracao-macica-dos-anos-60>). 
exterior $^{\prime \prime 86}$ funciona como uma espécie de mantra ao longo de toda a composição, iniciando e terminando cada uma das dez estrofes (cada uma com quatro versos) do poema. O emigrante percebe que, embora o "campo de grão floresça" depois de seu trabalho árduo e de que "Há mãos suas na bandeira do milho na espuma roxa do vinho", ele "vem de volta da vida" e "só traz a enxada"87. "Só tem pele e osso deixou as palavras nos dias de moço / foi moço e foi forte mas entranhou-se-lhe no corpo a morte" 1 , como acaba por acabar o fugitivo do poema de Ruy Belo, num fim não menos trágico que o de Severino de João Cabral:

- Nunca esperei muita coisa, é preciso que eu repita.

Sabia que no rosário de cidade e de vilas, e mesmo aqui no Recife ao acabar minha descida, não seria diferente a vida de cada dia: que sempre pás e enxadas foices de corte e capina, ferros de cova, estrovengas o meu braço esperariam.

Mas que se este não mudasse seu uso de toda vida, esperei, devo dizer, que ao menos aumentaria na quartinha, a água pouca, dentro da cuia, a farinha, o algodãozinho da camisa,

\footnotetext{
${ }^{86}$ BELO, 2000, p. 54.

${ }^{87}$ BELO, 2000, p. 54.

${ }^{88}$ BELO, 2000, p. 54.
} 
ao meu aluguel com a vida.

E chegando, aprendo que,

nessa viagem que eu fazia,

sem saber desde o Sertão,

meu próprio enterro eu seguia ${ }^{89}$.

Em Toda a terra, livro composto na maior parte por longos poemas de versos extensíssimos, Ruy Belo já havia consolidado uma segunda fase, onde assumiu definitivamente a torrencialidade de sua poesia, depois de ter atravessado um primeiro período, que vai de Aquele grande rio Eufrates (1961) a Homem de palavra(s) (1970), marcado pelo conflito precipitado na amplitude rítmica visível desde o início de sua produção ${ }^{90}$. Inclusive nesse segundo momento, embora dois anos antes de lançar Toda a terra, publica um livro que é todo ele um único poema, A margem da alegria, de 1974, o que nos mostra que aquela poesia, onde o "núcleo semântico se cristaliza" como "pura coisa de palavras" e que "contribui para a autonomização de cada fragmento e, logo, também para a sabotagem de um eventual 'todo', que o poema evita (ou não pode) exemplificar ou constituir" ${ }^{\prime \prime 1}$, como afirma Rosa Maria Martelo, acaba por dar cada vez mais lugar à "consciência de que o poema é um todo e deve subsistir por si em vez de se apoiar num momento

${ }^{89}$ MELO NETO, 2013, s/p.

${ }^{90}$ Ressalvemos que, sobre O problema da habitação - alguns aspectos, Ruy Belo já dizia "que [esse livro] é todo ele um longo poema" (BELO, 2002, p. 22.), ou então que "os meus dois primeiros livros [e aqui soma-se ainda $A G R E$ ] foram escritos num clima ascensional, em que eu caminhava para o poema longo" (BELO, 2002, p. 30.). Lembremos neste ponto que, como já indiciamos ao tratar de Homem de palavra(s), cada obra beliana nos surge "rigorosamente pensada na sua macro-estrutura, não se limitando a ser, como muitas vezes sucede com colectâneas poéticas, reuniões de certos textos datados de afinidades temáticas mais ou menos evidentes" (SILVESTRE, 1997, p. 10). ${ }^{91}$ MARTELO, 2012, p. 162. 
psicológico ${ }^{\prime \prime 92}$, com insistiu o poeta reafirmando em outra altura que "o poema é um todo constituído por palavras" e, portanto, "não é o que se escreve de uma só vez, de jacto, mas sim o conjunto de palavras que, mediante designadamente o recurso a figuras de retórica, conscientemente ou não, se apresente como um todo, uma unidade, embora eventualmente resultante de experiências dispersas quanto ao lugar e ao tempo" ${ }^{\prime 93}$.

A partir de A margem da alegria, esse triunfo do fragmento sobre o todo não é diligenciado, ou, nas palavras de Osvaldo Silvestre, "um certo desinvestimento na forma do poema [...] é compensado por um desdobrado investimento na formalivro" ${ }^{\prime 94}$, que se afasta do cânone modernista eliotiano ao assumir no poema longo "a disparidade dos seus motivos e referências e a permanente deslocação do seu horizonte de sentido, propondo-se como forma distendida, se não lassa" ${ }^{95} \mathrm{Ou}$, para mais, como argumentou Vasco Graça Moura sobre $A M A$ mas que se aplica a maior parte dos poemas dessa fase, "a convocação e organização de um contraponto histórico, sócio-político, intertextual e sentencional, por vezes completamente prosaico ou literalmente inexpressivo, acompanha desenvolvimento elegíaco das extensões conexas com a paixão e o destino trágico em linhas que são de alta voltagem poética"96, numa ironia que está na exploração desse contraste "por implicar que a história trágica de paixão é sempre uma história de veemência arrebatada no presente absoluto, carregando para o plano da contingência e da quase banalidade residual toda a matéria informativa ou documental que ele arranca factualmente ${ }^{\prime \prime 97}$.

\footnotetext{
92 BELO, 1984, p. 466.

${ }^{93}$ BELO, 2002, p. 264.

${ }^{94}$ SILVESTRE, 1997, p. 11.

${ }^{95}$ SILVESTRE, 1997, p. 10.

${ }^{96}$ MOURA, 2011, s/p.

${ }^{97}$ MOURA, 2011, s/p.
} 
Nessa segunda fase de Ruy Belo, inclusive marcada pelo afastamento do lirismo chistoso que encontramos em Manuel Bandeira e, em suma, na primeira geração do modernismo brasileiro, observamos correspondências com os próprios delineios entre lirismo e narratividade a que também assistimos em João Cabral de Melo Neto, especialmente com o seu poemalivro Morte e vida severina. Os poemas belianos, não obstante, em diálogo com um universo referencial em João Cabral também pertencem a essa segunda fase, que tem início com a publicação de Transporte no tempo (1973) e perdura até o final da obra de Ruy Belo, com Despeço-me da terra da alegria (1977). E não por acaso ainda ser A margem da alegria uma alusão ao conto As margens da alegria, de Guimarães Rosa, que tal como João Cabral, pertence à terceira geração modernista. Quer dizer, por contingência ou não, há um segundo momento na obra beliana que é consonante a determinados eixos de produção da Geração de 45 , sobretudo no que diz respeito aos cruzamentos entre poesia e prosa que marcam o intercâmbio geracional.

E assim, o poeta de "Canção do cavador", poema que analisamos há pouco, está longe daquele que escreveu, no seu então exórdio Aquele grande rio Eufrates, um outro poema intitulado canção, desta vez do lavrador. "Canção do lavrador" é um soneto estrambótico, com rimas externas e cruzadas, e que termina com o sugestivo verso "Poeta não escrevas lavra"98, fazendo-nos lembrar inclusive do "Profissão de fé" de Olavo Bilac, mas não propriamente pelo viés das similitudes, com o rigor formal e a metalinguagem. O diálogo que podemos estabelecer entre os dois poemas nos recorda pontos fulcrais de transição do parnasianismo para o modernismo: ora, enquanto Olavo Bilac compara o ofício do escritor ao de um ourives, é à imagem de um lavrador, aquele que tem as mãos no arado (para

${ }^{98}$ BELO, 2009, p. 62. 
evocar o título de outro poema beliano ${ }^{99}$ ), que está sempre exposto, na labuta diária, às condições do clima e da terra, a que Ruy Belo vai recorrer. Lavrar é cultivar a terra para que dela se possa colher, como o poeta o faz na sua "página de terra"100.

"Canção do lavrador" traz-nos ainda à memória, sobretudo ao manifestar a relevância da limagem em poesia, Graciliano Ramos e a descrição das lavadeiras de sua terra, que somente depois de lavarem, enxaguarem e torcerem as peças de roupa "pelo menos três vezes" é que as penduram na corda ou no varal, para secar: "Pois quem se mete a escrever devia fazer a mesma coisa. A palavra não foi feita para enfeitar, brilhar como ouro falso; a palavra foi feita para dizer"101. Ou então o próprio João Cabral de Melo Neto, ainda com o seu Morte e vida severina, em que a primeira estrofe da $14^{\mathrm{a}}$ parte pode ser lida como uma metáfora ao ato de escrever: “-E a língua seca de esponja / que tem o vento terral / veio enxugar a umidade / do encharcado lamaçal." 102

Por fim, é nesse mesmo AGRE de "Canção do lavrador" (aliás, livro em que "o monograma AGRE fixa um sintomático sinal agreste entre o alto e o baixo, o divino e o humano"103, e no qual "Canção do lavrador" é o prenúncio de que a terra agreste triunfaria, ao fim da obra beliana, em detrimento das mesuras celestes) onde vamos encontrar um outro poema, "Emprego e desemprego do poeta", que reitera, contudo, que apesar das diferenças de estilo demarcarem duas fases na produção poética de Ruy Belo, com Homem de palavra(s) a situar-se como a obra

${ }^{99}$ Neste caso é "A mão no arado", poema de O problema da habitação - alguns aspectos.

${ }^{100}$ BELO, 2009, p. 62.

${ }^{101}$ RAMOS in FRAGA, s/d, p. 1. Citação de uma entrevista a Graciliano Ramos realizada em 1948.

${ }^{102}$ MELO NETO, 2013, s/p.

${ }^{103}$ SILVEIRA, 2011, s/p. 
de transição, do primeiro ao último livro o poeta encara o seu ofício como exercício ${ }^{104}$, ou mesmo como estudo ${ }^{105}$ (duas palavras que, inclusive, intitulam poemas de $H P$ ). Talvez seja esta a característica premente do modernismo brasileiro em todas as suas fases - a obra entendida como construção, como trabalho artesanal ou mesmo como processo, longe da ideia romântica da inspiração divina ou genial do artista ou da perfeição formal como o genuíno fim por ele a ser alcançado, como propunham os parnasianos - mais latente, mais transversal a todo o percurso beliano, num poeta que no último poema do último livro que publica diz em assertiva e escorço, ao recordar uma vida marcada por tantos "Enganos e desencontros": "O meu desporto é a versificação"106.

\section{Referências bibliográficas}

ANDRADE, Carlos Drummond de. Poesia e prosa. 6. ed. Rio de Janeiro: Nova Aguilar, 1988.

ANDRADE, Oswald de. Obras completas. 2. ed. Rio de Janeiro: Saraiva, 2003.

ATHAYDE, Manaíra Aires. Os sulcos da morte na poesia de Ruy Belo. Revista de Estudios Portugueses, v. 1, n. 11, 2012.

BANDEIRA, Manuel. Poesia completa e prosa. 4. ed. Rio de Janeiro: Nova Aguilar, 1990.

BELO, Ruy. Aquele grande rio Eufrates. Lisboa: Edições Ática, 1961.

${ }^{104} \mathrm{O}$ "exercício da sabedoria da linguagem" ou "uma aventura da linguagem" (BELO, 2002, p. 317), como tantas vezes definiu a poesia. 105 Vide que a própria palavra "estudo" é utilizada por artistas das artes plásticas para designar os processos de construção de suas obras. ${ }^{106}$ BELO, 2009, p. 855. 
. Aquele grande rio Eufrates [1961]. 5. ed. Lisboa: Editorial Presença, 1996.

. Homem de palavra(s). Col. Cadernos de Poesia. Lisboa: Dom Quixote, 1970. 1997.

. Homem de palavra(s) [1970]. 5. ed. Lisboa: Editorial Presença, . Na senda da poesia [1969]. 2. ed. Lisboa: Assírio \& Alvim, 2002. . Todos os poemas. 3. ed. Lisboa: Assírio \& Alvim, 2009.

BLOOM, Harold. A angústia da influência: uma teoria da poesia. Trad. Miguel Tamen. Lisboa: Cotovia, 1991.

CRUZ, Gastão. Ruy Belo: as palavras inauguradoras. In: . A poesia portuguesa de hoje [1973]. 2. ed. Lisboa: Relógio d'Água, 1999.

CAMPOS, Álvaro de. Livro de versos. 2. ed. Lisboa: Editorial Estampa, 1993.

DE MAN, Paul. Autobiography as de-facement. MLN, v. 94, n. 5, dez. 1979. Disponível em: <http://neuron.mefst.hr/docs/katedre/med_ humanistika/Medicina/Narativna/AutobiographyAsDe_facement. pdf>. Acesso em: 13 dez. 2013.

FRAGA, Myriam. Catálogo Mestres da Literatura. Rio de Janeiro: Moderna, s/d. Disponível em: <http:/ /literatura.moderna.com.br/ catalogo/encartes/9788516054014.pdf>. Acesso em: 14 dez. 2013.

GALVÃO, Henrique. [Introdução]. In: BANDEIRA, Manuel. Manuel Bandeira: obras poéticas. Lisboa: Editorial Minerva, 1956. p. 1.

GOODMAN, Elise. The portraits of Madame de Pompadour: celebrating the femme savant. University of California Press, 2000.

HOLANDA, Sérgio Buarque de. Trajetória de uma poesia. In: BANDEIRA, Manuel. Poesia completa e prosa. 4. ed. Rio de Janeiro: Nova Aguilar, 1990.

LEAL, Christiana Lourenço. Os modalizadores em - mente no texto jornalístico de opinião. Cadernos do CNLF, v. 1, n. 12, 2012. Disponível em: <http://www.filologia.org.br/xcnlf/12/12.htm>. Acesso em: 14 dez. 2013. 
MARTELO, Rosa Maria. Alegoria, fragmentos e montagem nos poemas longos de Ruy Belo. In: . O Cinema da poesia. Lisboa: Documenta, 2012. p. 151-164.

MELO NETO, João Cabral de. A educação pela pedra e depois. Rio de Janeiro: Nova Fronteira, 1997.

. Morte e vida severina [1955]. In: NOGUEIRA, Arnaldo. Projeto Releituras. Disponível em: <http:/ / www.releituras.com/ joaocabral_morte.asp >. Acesso em: 13 dez. 2013.

MENDONÇA, José Tolentino. Ruy Belo, clandestino seguidor de Deus. In: BELO, Ruy. Aquele grande rio Eufrates [1970]. 5. ed. Lisboa: Editorial Presença, 1996.

MONTEIRO, Adolfo Casais. A poesia de Manuel Bandeira. In: BANDEIRA, Manuel. Poesias de Manuel Bandeira. Lisboa: Portugália, 1968.

MORAES, Emanuel de. Manuel Bandeira: análise e interpretação literária. Rio de Janeiro: José Olympio, 1962.

MOURA, Vasco Graça. Ruy Belo: lirismo, ironia, torrencialidade. Colóquio Internacional Ruy Belo: Homem de palavra(s). Lisboa: Fundação Calouste Gulbenkian, 2011.

SILVEIRA, Jorge Fernandes da. Ruy Belo: Brasil, País possível. Colóquio Internacional Ruy Belo: Homem de palavra(s). Lisboa: Fundação Calouste Gulbenkian, 2011.

SILVESTRE, Osvaldo. Introdução. In: BELO, Ruy. Boca bilingue [1966]. 4. ed. Lisboa: Editorial Presença, 1997. 


\section{Resumo}

Este ensaio tem o objetivo de reconhecer influências de três dos principais poetas brasileiros do século XX na poesia de Ruy Belo, tentando perceber de que forma as produções de Manuel Bandeira, Carlos Drummond de Andrade e João Cabral de Melo Neto foram assimiladas nos mecanismos de criação do poeta português. Reflete-se sobre várias dinâmicas de intertextualidade, voluntárias e não voluntárias, desde relações de ordem temática, ecfrástica ou de transposição poética, contextualizando-as no discurso poético de Ruy Belo.

\section{Abstract}

This essay aims to recognize influences of three major Brazilian poets of the twentieth century in the poetry of Ruy Belo, trying to understand how the production of Manuel Bandeira, Carlos Drummond de Andrade and João Cabral de Melo Neto was assimilated into mechanisms of creation of the Portuguese poet. It is reflected on various dynamics of intertextuality, voluntary and non-voluntary, as thematic relations, ekphrastic or poetic transposition, contextualizing them in the poetic discourse of Ruy Belo. 